\title{
Environmental Impact Assessment of reservoir construction: new perspectives for restoration economy, and development: the Belo Monte Power Plant case study
}

\author{
Tundisi, JG. ${ }^{a, b *}$, Matsumura-Tundisi, T. $^{a}$ and Tundisi, JEM. ${ }^{a}$ \\ anstituto Internacional de Ecologia - IIE, Rua Bento Carlos, 750, Centro, CEP 13560-660, São Carlos, SP, Brazil

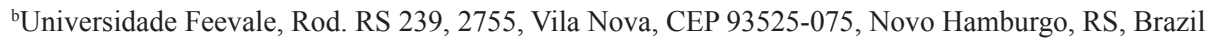 \\ *e-mail: tundisi@iie.com.br
}

Received: July 21, 2015 - Accepted: July 25, 2015 - Distributed: August 31, 2015

(With 2 figures)

\begin{abstract}
The Environmental Impact Assessment of reservoir construction can be viewed as a new strategic perspective for the economic development of a region. Based on the principles of a watershed approach a interdisciplinary and multidisciplinary systemic view including biogeophysiographical, economic and socio environmental studies the new vision of a EIA provides a basic substratum for the restoration economy and an advanced model for the true development much well ahead of the modernization aspects of the project of a reservoir construction.
\end{abstract}

Keywords: watersheds, reservoirs, development, restoration economy.

\section{Avaliação de Impacto Ambiental da construção de reservatórios: novas perspectivas para a economia da restauração e desenvolvimento, regional: o estudo de caso Belo Monte (UHE)}

\begin{abstract}
Resumo
A Avaliação de Impacto Ambiental (AIA) de reservatórios em construção deve ser considerada como uma nova perspectiva estratégica para o desenvolvimento regional muito mais avançada do que a modernização produzida pela infraestrutura. Baseada no princípio de abordagem sistêmica, interdisciplinar e multidisciplinar incluindo a base biogeofisiográfica, e estudo sócio ambientais, a nova visão da AIA promove um substrato básico para a economia da restauração e para um nível avançado de desenvolvimento muito além do mero processo de modernização produzido pela construção do reservatório. Estas mudanças de paradigma conceitual em governança, economia e sustentabilidade são fundamentais para o desenvolvimento avançado do país.
\end{abstract}

Palavras-chave: bacia hidrográfica, reservatórios, desenvolvimento, economia da restauração.

\section{Introduction}

A reservoir is intimately related with the watershed that is a biogeophysiographical boundary. A river or watershed is defined as "as entire area drained by a major river system and by its main tributaries" (Likens 1992; Revenga et al., 1998).

The reservoir ecological dynamics and functioning is controlled by the watershed and its uses and human activities as well as their natural structures such as rivers network, climatological, hydrological and ecological cycles. Degraded watersheds have a great impact in the functioning of reservoirs that are connected to them. Therefore a reservoir in a watershed depends upon a matrix of geomorphological, geological, hydrogeochemical and climatological natural characteristics and the coupling of human activities imposed upon these natural features. (Tundisi and Matsumura-Tundisi, 2012).
Watersheds can be evaluated by the ecosystem services that they can promote such as freshwater supply, biodiversity, (genetic, physiological, morphological) and the ecological complexity it harbours. Watershed conditions are related to areas of original or natural landscape forest cover, hydrographic network, natural areas/human uses and humanized areas subjected to anthropogenic impacts. (Jorgensen, et al., 2012; Periotto and Tundisi, 2013).

The following criteria can be applied to impact assessment: (quantification and qualification of impacts):

- Dimension of the impact.

- Location and spatial scale of impact.

- Temporal scale (short, medium long term). 
- Reversibility/Irreversibility, of the impact.

- Relevance for the ecosystem services.

- Magnitude of the impact: low, medium, high.

Besides the Environmental Impact Assessment the principle of restoration economy can be applied to a reservoir construction as stated by Cunningham (2002).

This author uses the terminology, "restaurative development" that is the re-built of an environment under stress. Restaurative development can be applied with success to reservoir construction since offers excellent opportunities for new and creative solutions not only to minimize impacts but to implement new regional perspectives in land development and sustainable exploitation.

\section{Basic Principles of an EIA of a Reservoir}

Since reservoirs are the recipients of all activities (natural and human causes) in the watersheds a first and fundamental basic principle of a Environmental Impact Evaluation of a reservoir construction is to determine the degree of organization, connectivity and ecological dynamics of the watershed in order to estimate the loads, the regions that will be impacted or changed by the reservoir construction and the ecological consequences of this new artificial environment imposed upon the natural system. Besides the biogeophysical evaluation of the watershed and the impact of reservoir construction it is imperative to introduce and develop in the EIA the economical and societal changes that will be their cause and its consequences. Today it is widely required that the economic and socio environmental component of the watershed is as important as the biogeophysical processes in the governance of the reservoir ecological dynamics and functioning. Human occupation of the watershed, demographic changes, migration patterns degree of urbanization, introduce new land use practices, transforming land cover, through deforestation, interfering in biogeochemical cycles, point and non point loads, of nutrients and suspended material precipitation patterns and drainage inputs. Migrations from rural to urban areas, attraction of thousands of new labourers, changes in sanitary conditions of the newly established populations are other components of the environment that have to be considered from the quantitative and qualitative point of view. The risk of transmission of diseases (waterborne diseases, vector borne diseases or "social diseases") should also be part of the component analyzed in the EIA of the reservoir construction. Also the impact of future climatological changes and variability and droughts on the regional scales, should be considered in the study. Reservoir construction in many regions is a factor of modernization. The aim of this change of paradigm in the EIA of a reservoir construction is to promote a true development perspective and vision of a restoration economy in the process very much ahead of a mere modernization activity. (Jorgensen et al., 2012).

\section{Methodology for EIA of Reservoir Construction}

Taking into account that the watershed is the basic unit for EIA of a reservoir construction a complete analysis of the watershed ecosystem and its ecological dynamics should be implemented immediately upon decision of the site, region and river to be impacted by the construction. It is fundamental from the strategic point of view of the watershed/river/ reservoir development to know the definition of the impact of the river: one reservoir, a cascade of reservoirs or several reservoirs located a the various sites in the watersheds. This will define the scale of the study-spatially and temporarily and the magnitude of the necessary analysis-qualitative and quantitative. Long series of historical data on the watershed/river, such as climatological/hydrological/ecological date are required.

The hydrological component and the water budget are fundamental processes that govern the watershed cycles ad dynamics. Precipitation, Runoff, Evapotranspiration, changes in water storage are basic components to be measured. The hydrologic pathways and the river ecodynamics, interferes with the biota (distribution, productivity, and biomass) are also other relevant components. (Martinelli et al., 2012).

The atmospheric deposition (dry or wet deposition) is another important component since it can include the input of chemical substances and elements.

The geology, weathering and erosion processes play a major role in shaping the landscape, the rivers hydrographic network and the loads to the future reservoir.

The hydrogeochemistry of the catchment is another component that connects soil, soil uses, watershed uses with water quality either as confirmation of impacts or conservation processes in the watershed.

\subsection{Biological processes}

Biodiversity and the composition and distribution the biota are extremely important for the understanding of input-output budgets on watersheds. Organisms accumulate organic matter; promote cycles of nitrogen, phosphorus and other elements throughout soil/water relationships, produce detritus and dead organic matter that can be a source of nutrients; biological processes, include terrestrial and aquatic organisms, biodiversity, distribution of organisms in the catchment, biomass and productivity, and interfere with water yield and water quality. (Agostinho et al., 2009).

\subsection{Elements budgets}

Phosphorus, nitrogen, carbon, sulfur and toxic metals move from the soil to the water to organism, therefore the element budget is another basic component of the EIA of the reservoir construction quantification of sulphur and carbon budget in catchments many be helpful in evaluating the relevance and the quantitative importance of the gas emissions, especially greenhouse gas emissions of the terrestrial and aquatic systems. Cycles of trace metals in the catchment should be evaluated also for a better element budget. 


\section{Temporal and Spatial Scales of EIA of Reservoir Construction}

One of the important features of a EIA for a reservoir construction is the determination of the temporal and spatial scales of the study, considering the Area of Direct Influence of the Reservoir and the Area of the Indirect Influence. However, stream discharges may vary greatly during heavy rainfall periods ;runoffs also vary throughout the watershed, therefore daily and seasonal variations should be incorporated into the analysis of the biogeophysical factors. For example climatology should be collected with hourly and daily information. It is important also to consider historical data over decades in order to analyze tendencies and future perspectives. Paleoecological methods introduced in order to detect physical, chemical and biological changes in the part present and future perspectives of the reservoir construction should be included in EIA. Figure 1 shows a scheme of all possible interactions to be taken into account in an EIA of reservoir construction.

\section{The Socio Environmental Component}

Interaction between the basic ecological processes, the biogeophysical components with the socio environmental economic ones were described and discussed in the Millennium Ecosystem Assessment initiative that promoted a new vision of ecosystem services for the human well being, and emphasized the need for a strong analysis of these components that are both causes and consequences of changes in the site of the reservoir construction (MEA, 2003). Evaluation of social processes associated with reservoir construction, sites of the migrating population, economic impacts in urban and rural areas, and the health situation both in the existing towns, rural and periurban regions, as well as in the construction sites is of fundamental importance in the overall impact assessment. Land cover, land use studies and its changes will provide insights into the new patterns of occupation of the landscape, and its future perspectives. To summarize, the installation of a "observatory" before and during the construction of the reservoir will be an important conceptual development in the work of a EIA (Tundisi et al., 2008, 2014).

As a complement to Table 1 the following information has to be obtained (Table 2) for a advanced EIA of a reservoir in a watershed.

\section{The Belo Monte Power Plant Case Study}

The construction of a reservoir has a very important impact in the functioning of ecosystems-rivers and their watersheds.

Belo Monte Power Plant reservoirs at the Xingu River State of Pará is the most important hydropower plant under construction in the last 10 years in Brazil. (Figure 2). The original project of Belo Monte was modified in order not only to mitigate impacts but to provide a strong planning process for the reservoir construction and the development of the region (see Saracura, this volume) The entire area of influence of the reservoir will be developed, specially the infrastructure, with employment and the business opportunities. Considering that indigenous rights and the ecological functioning of Xingu River are protected it can be said that in Belo Monte Power Plant a true sustainable development procedure was implemented .

The major consequence of the planning process for Belo Monte Power Plant is the operation scheme of the reservoir that will function as a flowthrough plant, reducing

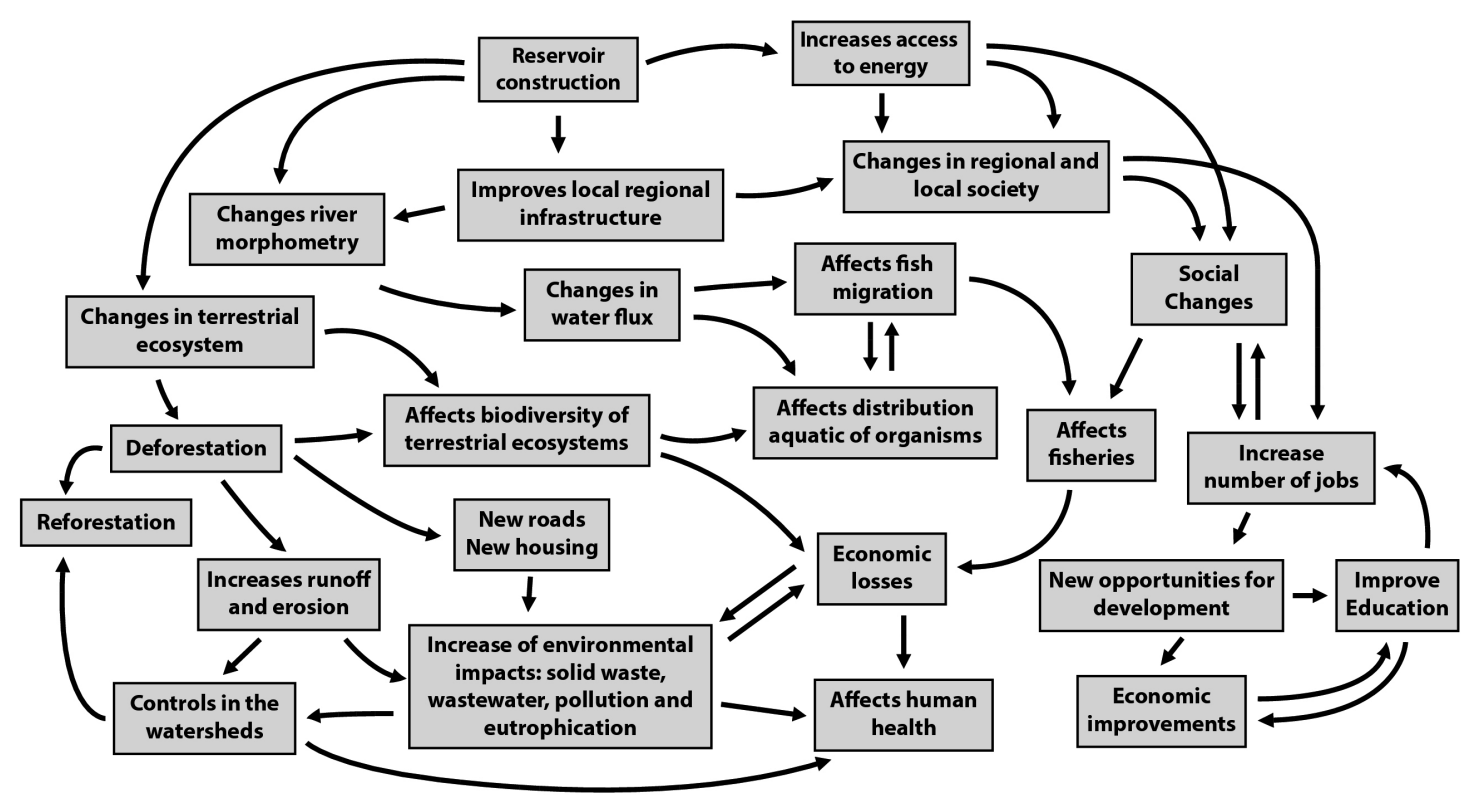

Figure 1. Network of interactions to be taken into account in the Environmental Impact Assessment of Reservoir Construction (Original J.G. Tundisi). 
Table 1. Basic measurements recommended for all catchments in a network (after Hornung et al., 1990).

\section{Site Data}

Main vegetation types and their spatial distribution,

Vegetation aboveground biomass of the main vegetation types. Leaf chemistry from main forest species at three - year intervals- for total C, N, P, Na, Mg, Ca.

Description of main soil types and their distribution. For main soil horizons of main soil types - cation

Soils exchange capacity, base saturation, exchangeable captions, organic matter content, total $\mathrm{C}$ and $\mathrm{N}, \mathrm{SO}_{4}{ }^{-2}$ adsorption, texture.

Parent material mineralogy, if different from bedrock.

Geology

Meteorological data
Main rock type and spatial distribution, mainly of each rock type

Mean monthly temperature, weekly precipitation the number of gauges being determined by variation in altitude within the catchment.

\section{Air pollution and dry deposition}

Measurement of atmospheric concentrations of $\mathrm{NH}_{3}, \mathrm{NO}_{2}$ and $\mathrm{SO}_{2}$ using simple adsorption techniques. Sampling interval to depend on ambient concentrations at each site.

\section{Inputs}

Bulk precipitation

Weekly samples composed for monthly analysis.

Weekly collections for monthly analysis form each

Throughfall forest type within the catchment. Several throughfall sites may be necessary if there is a large variation in aspect, altitude or age.

All samples to be analyzed for $\mathrm{pH}$, conductivity, calcium, magnesium, sodium, potassium, ammonium, nitrate, chloride, sulphate, filtered aluminium, and alkalinity. Occasional samples to be evaluated for $\mathrm{SiO}_{2}, \mathrm{DOC}$, total $\mathrm{P}$, Mn, organic N, Fe, Al speciation.

\section{Outputs}

Daily mean flow. Weekly spot samples analyzed in the same way as bulk precipitation and throughfall. From Commission of the European Communities, Brussels (Hornung et al., 1990).

Table 2. Basic information for prognosis of reservoir impacts.

Location of the reservoir in the river continuum

Size, volume, and morphometry of the future reservoir; possible compartmentalization

Retention time (planned for future operation)

Biodiversity in the impacted watershed

Soil uses and vegetation cover of the watershed

Human population, settlements, rural areas

Nutrient concentration in the main river and tributaries

The load of suspended organic and inorganic matter in the main river and its tributaries

The perspectives for multiple uses of the future reservoir

The projected future population in the watershed after dam construction

Future spatial heterogeneity patterns

Source: (Tundisi and Straskraba, 1999).

the area of the main reservoir and its flooding, therefore reducing the impact.

The other consequence is the reduction of the retention time. Accordingly to (Tundisi and Straskraba, 1999) and Straskraba (1999) retention time is the key factor that controls the water quality of a reservoir, and downstream.
The continuous optimization of the reservoir planning, the advanced operation system proposed, will provide a basis for reduction of the initial impact promoting sustainability and new perspectives for Amazonian reservoirs (Kennedy, 1999). As pointed out by Tundisi et al. (2014) the Amazon watersheds and rivers harbours a mega diversity 


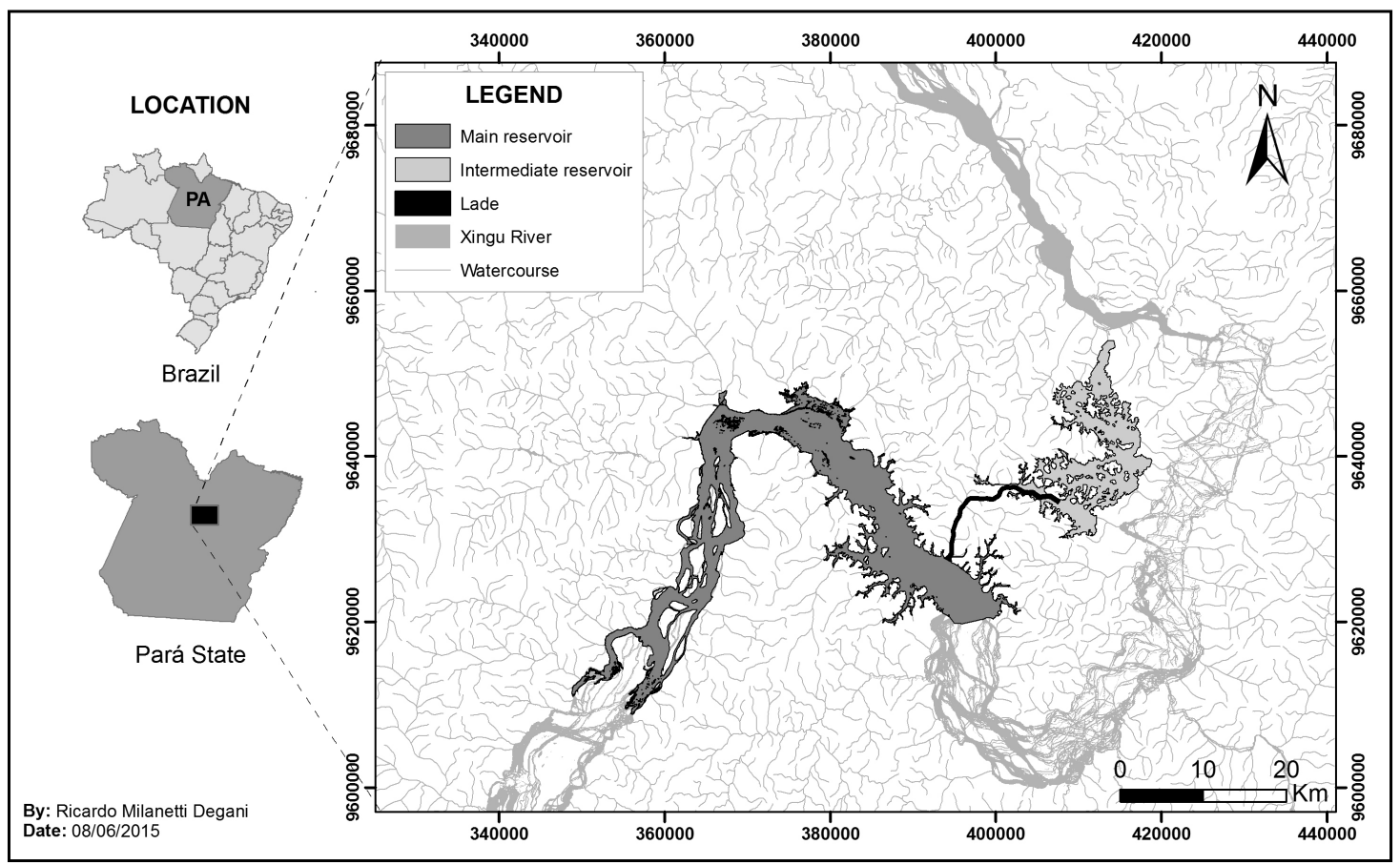

Figure 2. The Belo Monte Power Plant reservoirs in the Xingu River, Pará, state Brazil (Source: Norte Energia S.A., 2010).

of terrestrial and aquatic plants and animals. Mechanisms that maintain this biodiversity are the fluvial dynamics and the intense gene flux due to water level fluctuations and the interaction of climatological, hydrological, geomorphological and biological components of the system. Preserving these processes in the reservoir construction and operation is fundamental for the Amazon region reservoir construction. The lessons learned in Belo Monte, will be undoubted a valuable asset for planning and strategies for new reservoir construction in this region.

The understanding of the dynamics of the system will provide the basis for the implementation of a operation system of the reservoir which preserves water quality upstream and downstream and maintains connectivity between terrestrial and aquatic ecosystems. (Kennedy et al., 2003).

Considering this problem, connectivity of the river/ reservoir with the tributaries, a fundamental question arises: the resilience of a river ecosystem and its reservoirs will depend upon the degree of connectivity of the tributaries with the river/reservoir complex.

In order to question as a positive condition for the resilience (therefore maintaining it) a well preserved network of connected tributaries will be essential. This will prevent the river or reservoir to tip into a new state, due to impacts that pushes the system this a new state. (Schaeffer, 1998).

The designed operation system for the production of hydropower will maintain the connectivity of the tributaries, at the future Belo Monte Power Plant in its area of influence (Tundisi et al., 2013).

\section{Conclusions}

Environmental Impact Assessment of reservoir construction offers a new perspective for development, and opportunities for the implementation of restoration economy and restaurative development in the watersheds. The implementation of a planning procedure at an early stage of the evaluation and the inclusion of a systemic and integrated approach is fundamental for a sustainable project. (Ayensu et al., 1999). Analysis of the promotion of economic development versus preservation of biodiversity, ecological services, has to be considered at all stages of the construction with a permanent environmental commitment. Compensation and social programs are key for the future functioning of the reservoir and its impacts in the watersheds. Rather than to provide a mere description of the ecosystem and its components a understanding of the dynamics of the system and the interactions, connectivity of the components is the key concept for a true Environmental Impact Assessment, giving opportunities for new and creative development in the area of influence. This in turn will have an economic impact on the regional ecosystem preventing degradation, providing development altogether with a strong and decisive preservation of ecosystem services with all its several social, ecological and economical positive consequences (MEA, 2003).

The Belo Monte Power Plant promotes these opportunities. The reservoir construction and its operation system based and sustainable development is a new step towards the ecohydrological management of the watersheds in the Xingu River in the area of influence of the power plant. 


\section{References}

AGOSTINHO, AA., BONECKER CC., RODRIGUES L., GOVER, LC. and MAGELA THOMAZ S., 2009. Biodiversity and Conservation. Brazilian Journal of Biology, vol. 69, no. 2, supplement, p. 459-765.

AYENSU, E., VAN CLAASEN, DR., COLLINS, M., DEARING, A., FRESCO, L., GADGIL, M., GITAY, H., GLASER, G., JUMA, C., KREBS, J., LENTON, R., LUBCHENCO, J., MCNEELY, JA., MOONEY, HA., PINSTRUP-ANDERSEN, P., RAMOS, M., RAVEN, P., REID, WV., SAMPER, C., SARUKHÁN, J., SCHEI, P., TUNDISI, JG., WATSON, RT., GUANHUA, X. and ZAKRI, AH., 1999. International Ecosystem Assessment. Science, vol. 286, no. 5440, p. 685-686. http://dx.doi.org/10.1126/ science. 286.5440 .685 .

CUNNINGHAM, S., 2002. The restoration economy: the greatest new growth frontier. São Francisco: BR Publishers. 341 p.

HORNUNG, M., RODÁ, F. and LANGAM, SJ. (Eds.), 1990. A review of small catchments studies in Western Europe Producing hydrochemical budgets. Brussels: Commission of European Communities. 186 p. Air Pollution Research Report, no. 28.

JORGENSEN, SE., TUNDISI, JG. and MATSUMURA-TUNDISI, T., 2012. Handbook of Inland Aquatic ecosystem management. London: CRC Press Taylor \& Francis. 422 p. http://dx.doi. org/10.1201/b13038.

KENNEDY, R., 1999. Reservoir design and operation. Limnological implications and management opportunities. In TUNDISI, JG. and STRASKRABA, M. (Eds.). Theoretical reservoir ecology and its applications. Leiden: Backhuys Publishers. 585 p.

KENNEDY, R. and TUNDISI, JG., STRASKRABOVA, V., WIND, OT. and HEJLAN, J., (Eds), 2003. Reservoirs and the limnologists growing role in sustainable water resource management. Hydrobiologia, vol. 504, no. 1, p. xi-xii.

LIKENS, GE., 1992. The ecosystem approach: its use and abuse. In KINNE, O. (Ed.). Excellence in Ecology. Oldendorf: Ecology Institute. $166 \mathrm{p}$.

MARTINELLI, LA., OMETTO, JPHB. and SIQUEIRA PINTO, A., (Eds.), 2012. Climate change and biogeochemisthy: Brazilian Biomes. Brazilian Journal of Biology, vol. 72, no. 2, supplement, p. $633-785$.
Millenium Ecosystem Assessment - MEA, 2003. Ecosystems and human well being: a framework for assessment. Washington: Island Press. 245 p.

Norte Energia S.A., 2010. Plano básico de avaliação de impacto ambiental da UHE Belo Monte. Pará. 327 p.

PERIOTTO, NA. and TUNDISI, JG., 2013. Ecosystem services of UHE Carlos Botelho (Lobo/Broa): a new approach for management and planning of dams multiple user. Brazilian Journal of Biology, vol. 73, no. 3, p. 471-482. http://dx.doi.org/10.1590/ S1519-69842013000300003. PMid:24212686.

REVENGA, C., MURRAY, S., ABRAMOWITZ, J. and HAMMOND, A., 1998. Watershed of the world. Washington: WRI. $164 \mathrm{p}$.

SCHAEFFER, M., 1998. Ecology of shallow lakes. London: Chapman \& Hall. 357 p.

STRASKRABA, M., 1999. Retention time a fundamental variable in Limnology of reservoirs. In TUNDISI, JG. and STRASKRABA, M. (Eds.). Theoretical reservoir ecology and its applications. Leiden: Backhuys Publishers. p. 85-410.

TUNDISI, JG. and STRASKRABA, M., 1999. Theoretical reservoir ecology and its applications. Leiden: Backhuys Publishers. 585 p.

TUNDISI, JG., MATSUMURA-TUNDISI, T. and TUNDISI, JEM., 2008. Reservoirs and Humman well being: new challenges for evaluating impacts and benefits in the meotropics. Brazilian Journal of Biology, vol. 68, no. 4, supplement, p. 1133-1135. http:// dx.doi.org/10.1590/S1519-69842008000500020. PMid:19197483.

TUNDISI, JG. and MATSUMURA-TUNDISI, T., 2012. Limonology. London: CRC Press Taylor \& Francis. 854 p.

TUNDISI, JE., MATSUMURA-TUNDISI, T., MATSUMURA TUNDISI, JE., FARIA, CR., RODRIGUES FILHO, J., BLANCO, FP., ABE, D., SIDAGIS GALLI, C., TEIXEIRA SILVA, V. and MEDEIROS, RG., 2013. Environmental impact assessment of the future Belo Monte power plant in the Xingu River. IIEGA. 210 p. Report.

TUNDISI, JG., GOLDEMBERG, J., MATSUMURA-TUNDISI, T. and SARAIVA, A., 2014. How many more dams in the Amazon? Energy Policy, vol. 74, p. 703-708. http://dx.doi.org/10.1016/j. enpol.2014.07.013. 